\title{
Reflections on Sixty-Eight Years of Research on Race and Intelligence
}

\author{
Richard Lynn \\ Ulster Institute for Social Research, London NW26 9LQ, UK; Lynnr50@aol.com
}

Received: 1 April 2019; Accepted: 16 April 2019; Published: 24 April 2019

\section{Introduction}

I first encountered the question of race and intelligence sixty-eight years ago. This was in 1951 when I was a student reading psychology at Cambridge and attended Alice Heim's lectures on intelligence. She told us that Blacks in the United States had a lower IQ than Whites and this was attributable to discrimination, which she subsequently asserted in her book (Heim, 1954) [1]. She also told us of the UNESCO (1951) [2] statement that "Available scientific knowledge provides no basis for believing that the groups of mankind differ in their innate capacity for intellectual and emotional development." She did not tell us that this assertion was disputed by Sir Ronald Fisher (1951) [3], the Professor of Genetics at Cambridge, who wrote a dissent stating that evidence and everyday experience showed that human groups differ profoundly "in their innate capacity for intellectual and emotional development" and that "this problem is being obscured by entirely well-intentioned efforts to minimize the real differences that exist."

Nor did Alice Heim tell us that Henry Garrett, the Professor of Psychology at Columbia University, had argued that genetic factors are largely responsible for the lower IQ of Blacks than of Whites (Garrett, 1945) [4] so I and my fellow students at Cambridge were not well-informed about the issue of race differences in intelligence and its causes. Alice Heim was giving us the mainstream position among social scientists in the 1950s and this remained largely unchallenged in the 1960s. I believe the only person who challenged it was Henry Garrett (1961) [5], who designated it "the equalitarian dogma", but I did not know of him until much later. At this time I did not question the mainstream position among social scientists that Blacks and Whites have equal ability as my interest during these years was in personality and I was not thinking about intelligence.

It was in 1967 that I became interested in this issue. This came about when I moved to Ireland to take up a position as research professor at the Economic and Social Research Institute (ESIR) in Dublin. The purpose of the ESIR was to carry out research on the economic and social problems of Ireland and find policies that would help solve them. Foremost among these was that, at that time, Ireland was quite economically backward compared with Britain and I researched the literature to see what contribution I could make to this problem. It was not long before I discovered a study by John Macnamara (1966) [6] that reported that the IQ of Irish 12 year olds was 90, compared with 100 in Britain. It appeared that the low IQ was likely a significant cause of the Irish economic backwardness. I knew that intelligence was a determinant of earnings among individuals and that this was also true for groups. I knew of Cyril Burt's (1937) [7] book The Backward Child, in which he showed that children in the boroughs of London had different IQs and that these were highly correlated across the boroughs with the earnings of adults. I knew that this had also been shown by Maller (1933) [8] in the boroughs of New York city. It seemed likely that the same would hold for nations and, in particular, for the economic backwardness of Ireland. This was how I came to formulate the theory that differences in intelligence are an important determinant of national per capita incomes that I was to publish later, in collaboration with Tatu Vanhanen, in IQ and the Wealth of Nations (Lynn and Vanhanen, 2002) [9]. 
As I thought about this in 1968, I decided it would be wise to check Macnamara's study reporting the low Irish IQ. I asked two of my assistants, Ian Hart and Bernadette O'Sullivan, to carry out a further study and they did this by administering Cattell's Culture Fair test to a sample in Dublin. They found their sample had an IQ of 88 compared with 100 in Britain (Hart and O'Sullivan, 1970) [10] and therefore closely similar to the IQ of 90 that Macnamara had reported.

Although this confirmed Macnamara's study, it was a disconcerting result. I wondered whether it would be wise to publish my conclusion that the low IQ was a significant factor responsible for the economic backwardness of Ireland. I doubted whether this conclusion would be well received, particularly coming from an Englishman telling the Irish that they had a low IQ problem. Furthermore, it would raise the question of what policies could be adopted to solve the problem. These would be a set of eugenic policies that would raise the Irish IQ, such as the sterilization of the mentally retarded and incentives for graduates to have more children. Eugenic policies of this kind had been regarded as sensible by most informed people in the first half of the twentieth century but in the late 1960s they had begun to be repudiated. In many countries, eugenics societies closed themselves down or changed their names and that of their journals. In 1968, the British Eugenics Society ended the publication of its journal The Eugenics Review and replaced it with Journal of Biosocial Science and in 1969 the American Eugenics Society ended the publication of its journal Eugenics Quarterly and replaced it with Social Biology. Neither of these new journals published papers on eugenics. In addition, although eugenics societies had been founded in virtually all economically developed countries in the first half of the twentieth century, Ireland was an exception. Ireland at that time was a deeply Catholic country and the Catholics had been the only group, articulated by G. K. Chesterton, that had opposed eugenics in the first half of the twentieth century. By 1970, eugenics had become almost universally rejected. Virtually no-one supported eugenic programs anymore and anyone who proposed doing so would be accused of being a Nazi. For all these reasons, I did not think I could publish the low Irish IQ while I was in Dublin and I decided that, in order to do so, I would have to move.

In 1969, the consensus that there are no race differences in intelligence was challenged by Art Jensen in his paper How much can we boost IQ and scholastic achievement? [11] In this he argued that the 15 IQ point difference between Blacks and Whites in the United States was likely to have some genetic basis. To quote his words, "it is not an unreasonable hypothesis that genetic factors are implicated in the average Negro-White intelligence difference". This paper generated a storm of protest. I read Jensen's paper and concluded that he was right. I discussed it with Hans Eysenck who said he agreed and in 1971 [12], he published his book Race, Intelligence and Education, in which he summarised the evidence for this. About the same time, William Shockley began lecturing and publishing papers arguing that the Black IQ deficit is largely genetic (Shockley, 1971) [13] and this also generated a lot of publicity on account of his being a Nobel prize-winner for the invention of the transistor.

\section{Attacks from Equalitarians}

Jensen and Eysenck were subjected to many attacks from Equalitarians for expressing these views. Students at Jensen's University of California at Berkeley held protests and demanded that he be fired. His car tires were slashed and the university police provided bodyguards to protect him. He received threats, was spat on and was prevented from delivering lectures. I witnessed this hostility in the summer of 1971 at a conference in Liège at which Jensen was scheduled to give a lecture on race differences in intelligence. As he was about to speak, there were shouts of Zeig Heil! from the audience, but after some pleas from the chairman the shouts died down and Jensen was able to deliver his lecture. As I had read Jensen's work I did not learn anything new, except for the Zeig Heil! shouts that race differences excite a huge hostile emotional reaction in many people. After his lecture, I met up with Art and we had dinner together. He told me that in the late 1960s he began looking at the evidence on the Black-White difference in intelligence on the assumption that this was solely environmentally determined, but the more he considered the data, the more evident it became that genetic factors are also involved. In 1973 Hans Eysenck encountered similar hostility when he began to deliver a lecture 
at the London School of Economics. As soon as he started, a number of students went up and attacked him and broke his glasses.

An opportunity to move from Dublin came in 1971 when the University of Ulster advertised for the professorship of psychology. I applied, was offered the position and accepted, and moved to Ulster in 1972. I believed I would now be able to publish my conclusions on the low Irish IQ. I would also be able to work more generally on the relation of intelligence to national incomes and to the related issue of the relation of intelligence to regional differences in incomes within countries. I realised that this work would likely be met with the same hostility that Jensen and Eysenck had encountered and it was therefore important to research the evidence thoroughly and ensure it was sound before going public.

In the 1970s, Japan and Singapore were achieving rapid economic growth and I researched the issue of their IQs to examine the possibility that they might have high IQs that contributed to their economic development. I discovered that this was the case and in 1977, I published papers showing that the IQ in Japan was 106.6 and that the IQ in Singapore was 107 in relation to a British IQ of 100 (Lynn, 1977a, 1977b) [14,15].

The next year I published the first survey of national and racial differences in intelligence worldwide (Lynn, 1978) [16]. In this, I set the British IQ at 100 with a standard deviation of 15 and showed that the European peoples, including those in the United States, Australia and New Zealand, have same IQ, except for southern Europe, where the IQ was somewhat lower, falling to 89 in Greece. I gave the IQ in Iraq, Iran, India and sub-Saharan Africa as in the mid to low 80s; the IQ of Northeast Asians in Japan and Singapore as approximately 107; the IQ of Southeast Asians represented by Indonesia as 96; the IQ of Native American Indians as in the low 90s; the IQ of New Zealand Maori as approximately 94; the IQ of Micronesians and Polynesians as approximately 88; the IQ of Australian Aborigines as about 80; and the IQ of Kalahari Bushmen as approximately 55. These national and racial IQs have been largely confirmed by the numerous studies that have been published during the subsequent forty years that I have summarised in Lynn (2015) [17] and have been confirmed independently by David Becker in Lynn and Becker (2019) [18]. The only substantial differences are that the more recent data show the IQ of sub-Saharan Africans is approximately 70 and the IQ of Australian Aborigines is 62.

In 1982 I published a further paper on the IQ in Japan showing that this had increased during recent decades and proposing that improvements in nutrition have been largely responsible for this increase [19]. This prompted Jim Flynn to see whether the IQ had increased in the United States and two years later he reported that it had (Flynn, 1984) [20]. This inspired Dick Herrnstein and Charles Murray (1994) [21] in their book The Bell Curve to designate increases in intelligence the "Flynn effect". As I had shown the increase two years earlier, several people redesignated it the Lynn-Flynn effect or the LFlynn effect (Rindermann, 2018) [22]. Neither of these designations was appropriate, because about twenty people had previously reported increases in intelligence during the previous half century in studies that I have summarised in Lynn (2013) [23].

In the 1970s, I also looked at regional differences in intelligence within countries and their economic and social outcomes and in 1979-1981, I published three papers on these. The first gave IQs for the regions of the British Isles showing that the average IQ is highest in London and Southeast England and declines successively in the English provinces, Scotland and Northern Ireland and is lowest in the Republic of Ireland and that these IQs are highly correlated with per capita incomes and a number of other socio-economic phenomena, including infant mortality and intellectual achievements (Lynn, 1979) [24]. In this paper I was able to give further studies showing that the IQ in the Republic of Ireland is significantly lower than that in Britain and I attributed this to selective migration of the more intelligent from Ireland to Britain, the United States and elsewhere. Some forty years later, these regional IQ differences were confirmed for the United Kingdom (excluding the Irish Republic) by Noah Carl (2016) [25]. The next year I published a paper giving IQs for 79 regions of France showing that the average IQ is highest in Paris and that the regional IQs are highly correlated with per capita 
incomes, infant mortality and intellectual achievements (Lynn, 1980) [26]. A year later I published similar data for Spain (Lynn, 1981) [27].

During the 1980s I collected more data on race differences in intelligence and also carried out some studies on race differences in reaction times. I published these in Lynn (1991a) [28]. This gave the IQ of Europeans as 100, except in the south where it declines to the mid-90s; 106 for Northeast Asians; 92 for New Zealand Maori; 86 for Native American Indians; 86 for South Asians represented by India; 70 for sub-Saharan Africans; and 79 for Australian Aborigines. Subsequent studies have shown that these IQs are about right except for Australian Aborigines for whom the IQ is now estimated as 62 (Lynn, 2015) [17] The studies of race differences in reaction times were carried out on 9 year olds and showed that these were fastest among the Chinese in Hong Kong and successively slower in the Japanese, British, Irish and Blacks in South Africa. Thus, these reaction time differences were highly correlated with the intelligence differences in these five populations.

Later in the same year I published a paper on how these race differences could have evolved and proposed the cold winters theory, stating that higher intelligence was selected for in the colder environments of Europe and Northeast Asia during the last ice age and was the principal factor responsible for the evolution of greater intelligence in the European and Northeast Asian peoples (Lynn, 1991b) [29]. This theory has now become widely accepted, e.g., by Miller (1991) [30], Rushton (1995) [31] and Rinderman (2018) [22]. I believe the only dissent has come from Flynn (this issue) who argues that the high intelligence of the southern Chinese cannot be explained by cold winters because they were south of the Himalayas during the last ice age and were not exposed to its cold winters and only subsequently migrated into southern China. He does not offer any evidence for this speculation and it has been refuted by Frost (this issue).

In the 1990s, I collected more data on race differences in intelligence and also published books on dysgenics, i.e., the decline of genotypic intelligence from the late nineteenth century resulting principally from the low fertility of higher IQ women (Lynn, 1996) [32] and a sequel on eugenics setting out policies for reversing the dysgenic decline (Lynn, 2001) [33].

In 2000, I returned to the issue of national differences in intelligence and their contribution to economic development. I worked on this with Tatu Vanhanen, a political scientist in Finland, and we published our conclusions in our book IQ and the Wealth of Nations (Lynn and Vanhanen, 2002) [9]. In this I gave IQs for all major 185 nations in the world and Tatu Vanhanen gave the per capita income measured as real GDP (gross domestic product). We showed that national IQs were significantly correlated at 0.62 with per capita income and therefore that national IQs explained 38 percent of the variance in national per capita income $(0.62$ squared $=0.38)$.

We were not wholly surprised that this claim received a mixed reception. Among our negative critics were Earl Hunt and Robert Sternberg (2006) [34] who described them as "technically inadequate ... and meaningless". Others were supportive, including Erich Weede and Sebastian Kampf (2002) [35] who wrote that "there is one clear and robust result: Average IQ does promote growth" and Edward Miller (2002) [36] wrote that "the theory helps significantly to explain why some countries are rich and some poor".

In 2006 Tatu Vanhanen and I published a further study of national IQs and economic development in our book IQ and Global Inequality [37] and in 2012, we published a third study in our book Intelligence: A Unifying Construct for the Social Sciences. In this we confirmed that national IQs are significantly correlated with per capita income and showed that national IQs are significantly correlated with a number of other phenomena, including positively with income inequality assessed by the Gini index (0.47), number of researchers in research and development (0.67), life satisfaction (0.63), life expectancy (0.76), quality of water (0.62) and quality of sanitation (0.71); and negatively with the rate of unemployment $(-0.76)$, gender inequality $(-0.86)$, corruption $(-0.59)$, religious belief $(-0.48)$, malnutrition (-0.52) and tuberculosis (-0.57),

These additional correlates validated our national IQs and a number of scholars came to accept the validity of these and their contribution to a wide range of economic and social phenomena. 
Matrin Voracek (2013) [38] wrote that "The publication of a compilation of national intelligence (IQ) estimates for the world's countries by Lynn and Vanhanen has spawned considerable interest among researchers across a variety of scientific disciplines ... Up to now, across dozens of studies, theoretically expected and thus meaningful aggregate-level associations of national IQ with numerous other psychological, socioeconomic, and demographic indicators have been obtained." The validity of our national IQs was also endorsed by Sergey Kulivets and Dmitri Ushakov (2016) [39] of the Russian Academy of Sciences. They wrote: "We propose that problem solving is the mediator between human competencies and achievements. Creation of goods and services is based on problem solving in design, production and delivery...The simulation reproduces the most important traits of Lynn and Vanhanen's (2002) [9] findings." Even Earl Hunt, who initially rejected our national IQs as meaningless, conceded that "in spite of the weaknesses in several of their data points Lynn and Vanhanen's empirical conclusion was correct" (Hunt and Wittmann, 2008) [40].

At the same time that I was working with Tatu Vanhanen on national IQ, I continued to work on the related issue of racial IQs. In 2006 I published Race Differences in Intelligence: An Evolutionary Analysis. I followed this with a second updated edition in 2015. This summarised the results of several hundred studies and the second gave the following IQs: Northeast Asians: 105; Europeans in Northern, Central and Western Europe, North America, Australia and New Zealand: 100; Eastern Europeans: 97; Southern Europeans: 92-96; Arctic peoples: 91; Maori: 90; Hispanics (US) 89; Native Americans: 86; Pacific Islanders: 85; South Asians: 84; North Africans: 83; sub-Saharan Africa: 71; Australian Aborigines: 62; Pygmies: 57; Bushmen: 55. These IQs have been generally confirmed by Heiner Rindermann (2018) [22] in his book Cognitive Capitalism: Human Capital and the Wellbeing of Nations, in which he gives updated national IQs, which he prefers to call cognitive abilities (CAs), for all 200 nations of any significant size in the world calculated from tests of intelligence and educational attainment in the PISA (Programme for International Student Assessment), TIMSS (Trends in International Mathematics and Science Study) and similar studies. He gives a correlation of 0.82 for 161 countries between national cognitive abilities and per capita income assessed as logged GDP in 2010, showing that two thirds of the variance in national per capita income can be explained by the cognitive abilities of the populations. This correlation is a little higher than those we reported in 2002 at 0.62 for 185 countries for GDP per capita and in 2012 at 0.71 for 192 countries.

During these years I wrote two more papers on regional differences in intelligence and their economic and social correlates in countries. The first of these was for Italy, which reported the highest IQ in the north and declining IQs in the south and that these predicted differences in income, education attainment and infant mortality (Lynn, 2010, 2011) [41,42]. I attributed the lower IQs in the south to the immigrants with lower IQs from North Africa and the Near East. The second was for Spain and reported similarly the highest IQ in the north and associated economic and social correlates and likewise attributed the lower IQs in the south to the immigrants with lower IQs from North Africa and the Near East (Lynn, 2012) [43].

Tatu Vanhanen died in 2015 and I recruited David Becker to work with me on a further update of national IQs and their correlates. We published these in 2019. David Becker wrote the chapter giving the updated national IQs and showed that these range between of 69 in sub-Saharan Africa and 105 in Northeast Asia and are therefore closely similar to those of 67 in sub-Saharan Africa and 105 in Northeast Asia given in our 2012 compilation; for the whole dataset, his updated national IQs were correlated at 0.87 with those we gave in Lynn and Vanhanen (2012) [44]. I wrote the chapter summarising the several hundred studies of the causes, correlates and consequences of national IQs. This documented that national IQs are significantly causal to educational attainment, per capita income, economic growth, income inequality, cognitive achievements, political institutions (e.g., democracy, market economy), happiness, religion, health, nutrition, crime and fertility and significantly the result of differences in race and ethnicity, morphology and physiology (e.g., brain size), geographical location (latitude) and genetics. I also wrote the final chapter on the future of national IQs. I argued that the difference between high and low IQ nations will decline as IQs in low IQ nations will increase, while 
those in European nations will decline as a result of dysgenic fertility and immigration. I concluded intelligence will continue to increase in Northeast Asia and that China is likely to emerge as the world's superpower in the second half of the twenty-first century.

I was surprised in 2017 to get an invitation from Robert Sternberg to contribute a chapter on my national IQs to a book he was editing on intelligence. He wrote that he was inviting the nineteen most cited psychologists on intelligence to contribute chapters on their work and that, as I was one of these, he was extending the invitation to me. I accepted and sent him The Intelligence of Nations, which he duly included (probably reluctantly) in the book. Thus, in the twelve years from 2002 to 2018, my national IQs had evolved from "technically inadequate ... and meaningless" (Hunt and Sternberg, 2006) [34] to mainstream acceptance published by the Cambridge University Press (Sternberg, 2018).

\section{More Attacks from Equalitarians}

The attacks in 1969-1973 by Equalitarians on Art Jensen and Hans Eysenck continued throughout the subsequent years on pretty much all of us who wrote contending that there are racial and national differences in intelligence. In the United States, it is virtually impossible to fire academics with tenure at universities, but others have been fired and attacked in other ways. Some of the notable instances are the attack on James Watson in 2007 after he gave an interview in which he had said that he was "inherently gloomy about the prospect of Africa because all our social policies are based on the fact that their intelligence is the same as ours whereas all the testing says not really". This observation created a great furore. Watson was in Britain at the time to give lectures at the Science Museum in London and at the universities of Oxford, Cambridge, Birmingham, Bristol and Edinburgh. His lecture at the Science Museum was instantly cancelled. A spokesperson for the museum explained that "We feel Dr. Watson has gone beyond the point of acceptable debate and we are, as a result, cancelling his talk." The universities of Birmingham and Edinburgh also cancelled his lectures. The Board of Trustees of the Cold Spring Harbor Laboratory in Long Island where Watson was chancellor issued a statement that it "vehemently" disagreed with Watson's comments, suspended him from his position and demanded that he resign or he would be fired. Watson opted to resign to avoid being dismissed. In January, 2019, Watson participated in a TV documentary in which he said that his views on race and intelligence had not changed. He said "There's a difference on the average between Blacks and Whites on IQ tests," and "I would say the difference is...genetic." The next day, the Board of Trustees of the Cold Spring Harbor Laboratory stated that "Dr. Watson's statements are reprehensible, unsupported by science, and in no way represent the views of CSHL, its trustees, faculty, staff or students. The Laboratory condemns the misuse of science to justify prejudice" and his latest comments are "utterly incompatible with our mission, values, and policies, and require the severing of any remaining vestiges of his involvement". The Trustees stripped him of his remaining honorary titles, including honorary trustee and chancellor emeritus.

Another victim of the Equalitarians in the United States was Jason Richwine, who had received a PhD from Harvard in 2009 with a dissertation IQ and Immigration Policy, in which he argued that Hispanics and Blacks have lower average IQs than Whites, that this has a genetic basis and, as a result, they have difficulty assimilating and are a drain on the economy and therefore their immigration should be reduced. After leaving Harvard, Richwine worked briefly at the American Enterprise Institute and then joined the Heritage Foundation and published articles repeating these arguments. In 2013, he published a study of the fiscal effects of an immigration amnesty in the United States, arguing that the costs would amount to $\$ 6.3$ trillion, and recommended that the United States should not let in immigrants with low IQs. This proposal was widely denounced in the media. A week later the Heritage Foundation fired him.

Charles Murray wrote on this: "His resignation is emblematic of a corruption that has spread throughout American intellectual discourse. I have a personal interest in this story because Jason Richwine was awarded a fellowship from my employer, the American Enterprise Institute, in 2008, and I reviewed the draft of his dissertation. A re-reading of the dissertation last weekend confirmed 
my recollection that Richwine had meticulously assembled and analyzed the test-score data, which showed exactly what he said they showed: Mean IQ-score differences between Latinos and non-Latino Whites, found consistently across many datasets and across time after taking factors such as language proficiency and cultural bias into account."

In February 2017, Charles Murray was attacked by students at Middlebury College in Vermont while about to give a lecture. Although he has never stated a belief that the low Black IQ has a genetic basis, he has become a hate figure for liberal students on account of his book The Bell Curve on race differences in IQs (written with Dick Herrnstein) and of his "Murray's law", a set of conclusions in his book Losing Ground: American Social Policy, 1950-1980, stating that social welfare programs for the poor encourage them to go on welfare and increase their numbers.

There have also been attacks by Equalitarians on a number of those in Europe who have written that there are racial and national differences in intelligence. In Britain in 1997, Christopher Brand was fired from his lectureship at Edinburgh University following the publication of his book The $g$ Factor, in which he wrote that general intelligence is an important factor in determining life outcomes. $\mathrm{He}$ attributed the lower socio-economic status of Blacks to their lower intelligence and described himself as a race realist. Following these statements, students and a mob of the Anti-Nazi League disrupted his lectures and his book was withdrawn by the publisher John Wiley. Edinburgh University fired him for conduct that "brought the university into disrepute". Brand sued the university for unfair dismissal, won and received $£ 12,000$, but he was not reinstated.

In 2006, Frank Ellis, a lecturer in Russian at the University of Leeds, gave an interview for the students' newspaper in which he said that Blacks have, on average, a lower IQ and poorer academic achievement than Whites. The vice-chancellor of the university instituted disciplinary proceedings against him and threatened him with dismissal. The result of this was that Frank Ellis was forced to retire on a modest pension.

In October, 2018, the International Association of Educational and Vocational Guidance in Sweden invited Linda Gottfredson to give a keynote address on her work on vocational aspirations, but subsequently disinvited her when it discovered she had published work on the genetic basis of race differences in intelligence.

My own experiences of attacks from Equalitarians have been fairly modest. When my book Race Differences in Intelligence was published in 2006, Bill Regnery sent an advertisement for it to the Mensa Bulletin, published by American Mensa, but the editor declined to take it. He wrote to Bill Regnery "As I explained on the phone a few minutes ago, and according to the advertising policies published in each edition of the Mensa Bulletin, all advertising materials and copy are subject to approval or rejection by the publisher. After reviewing the content of your ad for the book Race Differences in Intelligence by Richard Lynn, excerpts from the book, and related Web sites, we have decided not to accept this ad for publication in the Mensa Bulletin." This was an example of the informal censorship of studies showing race differences that has become increasingly prevalent.

When I was at the University of Ulster, coachloads of the Anti-Nazi League came to the university on two occasions, disrupted my lectures and put up posters demanding my dismissal. The university authorities should have called the police as they were causing an affray but did nothing to stop them. When I retired in 1995, I was appointed professor emeritus. In February, 2018, the students' union passed a motion demanding that my status as emeritus professor be rescinded because my publications documenting race and sex differences in intelligence might be hurtful to minorities and women. In March, the vice-chancellor informed me that the university had acceded to this demand. I believe this is the only time an emeritus professor has had his title revoked. And so with this act of petty vindictiveness I have achieved a unique distinction.

Looking towards the future, I agree with Jim Watson who wrote at the end of his autobiography that "There is no reason to anticipate that the intellectual capacities of peoples geographically separated in their evolution should prove to have evolved identically" and "when asked how many years would pass before the genes affecting differences in human intelligence would be found, my back-of-the 
envelope answer would be fifteen years" (Watson, 2007, p. 326) [45]. Large studies that identify genes (rather, genetic variants) associated with intelligence have been published since 2013 (Rietveld et al.) [46], with the most recent study being Lee et al. (2018) [47]. Piffer (2019; this issue) [48] reported the newest analysis of how these genetic variants related to group differences worldwide and found that they are roughly in line with known group differences, though his claims are still controversial. When the causal genetic variants are more definitely identified we can anticipate a huge hostile reception. Many scientists will not dare to give their opinion on it and those who endorse it will be viciously attacked. The uproar will be comparable to that following Charles Darwin's publication of his Origin of Species in 1859 which undermined faith in Christianity and about which one old lady is said to have observed "Let us hope it is not true; if it is true, let us hope the lower classes to not hear of it." Eventually, however, it will become accepted. Magna est veritas, et praevalebit.

\section{References}

1. Heim, A. The Appraisal of Intelligence; Methuen: London, UK, 1954.

2. UNESCO. The Race Concept: Results of an Inquiry; UNESCO: Geneva, Switzerland, 1951.

3. Fisher, R.A. Dissenting statement to UNESCO's. In The Race Concept: Results of an Inquiry; UNESCO: Geneva, Switzerland, 1951.

4. Garrett, H.E. Facts and interpretations regarding race differences. Science 1945, 102, 404-406. [CrossRef] [PubMed]

5. Garrett, H.E. The equalitarian dogma. Perspect. Biol. Med. 1961, 4, 480-484. [CrossRef] [PubMed]

6. Macnamara, J. Bilingualism and Primary Education; University of Edinburgh Press: Edinburgh, Scotland, 1966.

7. Burt, C.L. The Backward Child; University of London Press: London, UK, 1937.

8. Maller, J.B. Economic and social correlatives of school progress in New York City. Teach. Coll. Record 1933, 34, $655-670$.

9. Lynn, R.; Vanhanen, T. IQ and the Wealth of Nations; Praeger: Westport, CT, USA, 2002.

10. Hart, I.; O'Sullivan, B. Inter-generational social mobility and individual differences among Dubliners. Econ. Soc. Rev. 1970, 2, 1-18.

11. Jensen, A.R. How much can we boost IQ and scholastic achievement? Harvard Educ. Rev. 1969, 39, 1-12. [CrossRef]

12. Eysenck, H.J. Race, Intelligence and Education; Maurice Temple Smith: London, UK, 1971.

13. Shockley, W. Negro Iq Deficit: Failure of a "Malicious Coincidence" Model Warrants New Research Proposals. Rev. Educ. Resea. 1971, 41. [CrossRef]

14. Lynn, R. The intelligence of the Japanese. Bull. Br. Psychol. Soc. 1977, 30, 69-72.

15. Lynn, R. The intelligence of the Chinese and Malays in Singapore. Mank. Q. 1977, 18, 125-128.

16. Lynn, R. Ethnic and racial differences in intelligence: International comparisons. In Human Variation: The Biopsychology of Age, Race, and Sex; Osborne, R.T., Noble, C.E., Weyl, N., Eds.; Academic Press: New York, NY, USA, 1978.

17. Lynn, R. Race Differences in Intelligence: An Evolutionary Analysis, 2nd Revised ed.; Washington Summit Publishers: Augusta, GA, USA, 2015.

18. Lynn, R.; Becker, D. The Intelligence of Nations; Ulster Institute for Social Research: London, UK, 2019.

19. Lynn, R. IQ in Japan and the United States shows a growing disparity. Nature 1982, 297, 222-223. [CrossRef]

20. Flynn, J.R. The mean IQ of Americans: Massive gains 1932 to 1978. Psychol. Bull. 1984, 95, 29-51. [CrossRef]

21. Herrnstein, R.J.; Murray, C. The Bell Curve; Free Press: New York, NY, USA, 1994.

22. Rindermann, H. Cognitive Capitalism: Human Capital and the Wellbeing of Nations; Cambridge University Press: Cambridge, UK, 2018.

23. Lynn, R. Who discovered the Flynn Effect? A review of early studies of the secular increase of intelligence. Intelligence 2013, 41, 765-769. [CrossRef]

24. Lynn, R. The social ecology of intelligence in the British Isles. Br. J. Soc. Clin. Psychol. 1979, 18, 1-12. [CrossRef]

25. Carl, N. IQ and socio-economic development across regions of the British Isles. J. Biosoc. Sci. 2016, 48, 406-417. [CrossRef] 
26. Lynn, R. The social ecology of intelligence in the France. Br. J. Soc. Clin. Psychol. 1980, 19, 325-331. [CrossRef]

27. Lynn, R. The social ecology of intelligence in the British Isles, France and Spain. In Intelligence and Learning; Friedman, M.P., Das, J.P., O'Connor, N., Eds.; Plenum: New York, NY, USA, 1981.

28. Lynn, R. Race differences in intelligence: A global perspective. Mank. Q. 1991, 31, 254-296.

29. Lynn, R. The evolution of race differences in intelligence. Mank. Q. 1991, 32, 99-173.

30. Miller, E.M. Climate and intelligence. Mank. Q. 1991, 32, 127-131.

31. Rushton, J.P. Race, Evolution and Behavior; Transaction Publishers: Rutgers University, NJ, USA, 1995.

32. Lynn, R. Dysgenics: Genetic Deterioration in Modern Populations; Praeger: Westport, CT, USA, 1996.

33. Lynn, R. Eugenics: A Reassessment; Praeger: Westport, CT, USA, 2001.

34. Hunt, E.; Sternberg, R.J. Sorry, wrong numbers: An analysis of a study of a correlation between skin color and IQ. Intelligence 2006, 34, 121-139. [CrossRef]

35. Weede, E.; Kampf, S. The impact of intelligence and institutional improvements on economic growth. Kyklos 2002, 55, 361-380. [CrossRef]

36. Miller, E.M. Differential intelligence and national income. J. Soc. Political Econ. Stud. 2002, 27, 513-522.

37. Lynn, R.; Vanhanen, T. IQ and Global Inequality; Washington Summit Publishers: Augusta, GA, USA, 2006.

38. Voracek, M. National intelligence estimates and the failed state index. Psychol. Rep. 2013, 113, 519-524. [CrossRef]

39. Kulivets, S.; Ushakov, D. Modeling relationship between cognitive abilities and economic achievements. Psychol. J. High. Sch. Econ. 2016, 13, 636-648.

40. Hunt, E.; Wittmann, W. National intelligence and national prosperity. Intelligence 2008, 36, 1-9. [CrossRef]

41. Lynn, R. In Italy, north-south differences in IQ predict differences in income, education and infant mortality. Intelligence 2010, 38, 93-100. [CrossRef]

42. Lynn, R. New data confirm that IQs in Italy are higher in the north: A reply to Felice \& Giugliano. Intelligence 2011, 40, 255-259.

43. Lynn, R. North-south differences in Spain in IQ, educational attainment, per capita income, literacy, life expectancy and employment. Mank. Q. 2012, 52, 265-291.

44. Lynn, R.; Vanhanen, T. Intelligence: A Unifying Construct for the Social Sciences; Ulster Institute for Social Research: London, UK, 2012.

45. Watson, J.D. Avoid Boring People; Oxford University Press: Oxford, UK, 2007.

46. Rietveld, C.A.; Medland, S.E.; Derringer, J.; Yang, J.; Esko, T.; Martin, N.W.; Koellinger, P.D. GWAS of 126,559 individuals identifies genetic variants associated with educational attainment. Science 2013, 340, 1467-1471. [CrossRef]

47. Lee, J.J.; Wedow, R.; Okbay, A.; Kong, E.; Maghzian, O.; Zacher, M.; Fontana, M.A. Gene discovery and polygenic prediction from a genome-wide association study of educational attainment in 1.1 million individuals. Nat. Genet. 2018, 50, 1112. [CrossRef]

48. Piffer, D. Evidence for Recent Polygenic Selection on Educational Attainment and Intelligence Inferred from Gwas Hits: A Replication of Previous Findings Using Recent Data. Psych 2019, 1, 55-75. [CrossRef]

(C) 2019 by the author. Licensee MDPI, Basel, Switzerland. This article is an open access article distributed under the terms and conditions of the Creative Commons Attribution (CC BY) license (http://creativecommons.org/licenses/by/4.0/). 